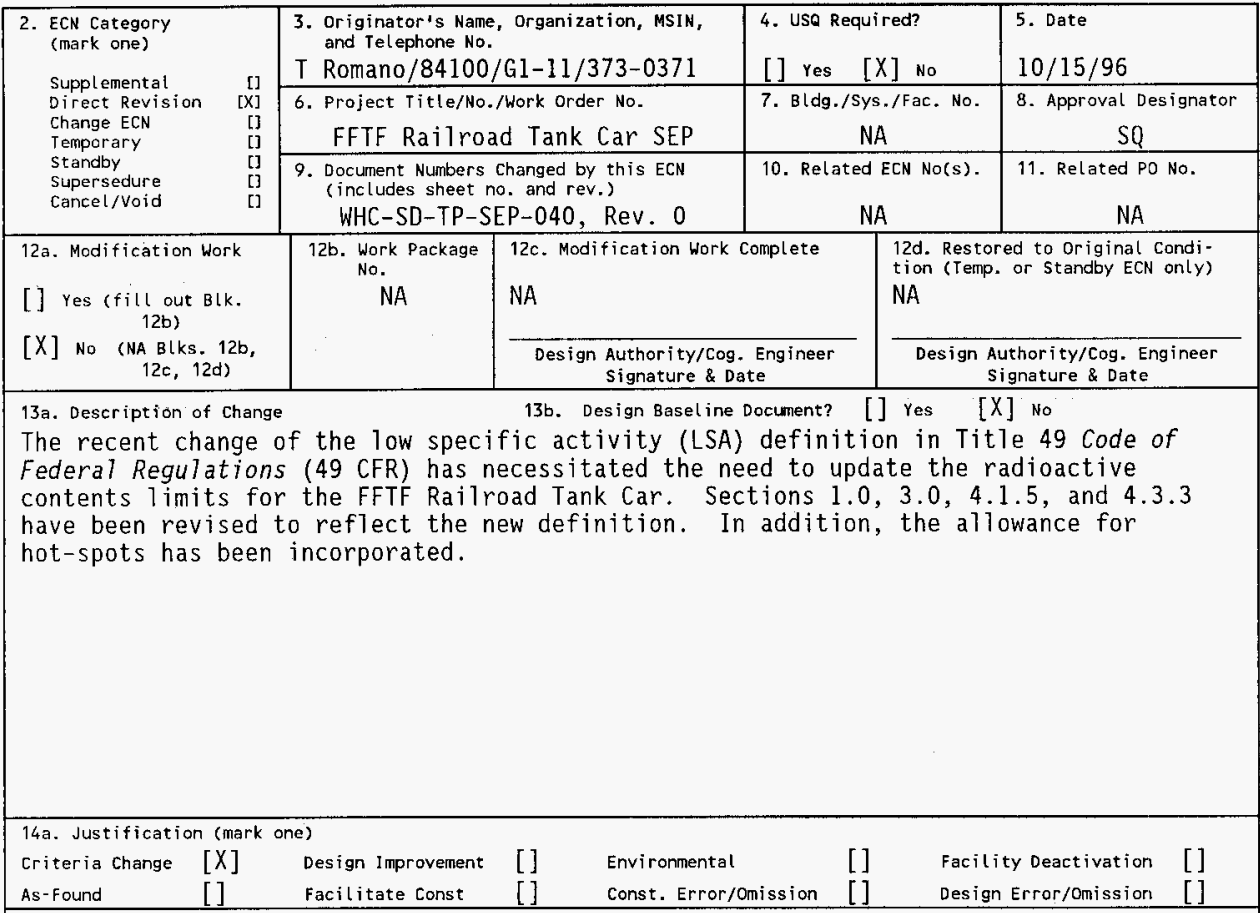

14b. Justification Details

Changes to 49 CFR require a revision of the SEP to implement new requirements and changes.

Design verification of these changes was performed and the changes were found not to adversely impact underlying safety bases and parameters of the package.

verfication performed by: f. lleud 10/23/96

15. Distribution (include name, MSIN, and no. of copies)

See attached. 


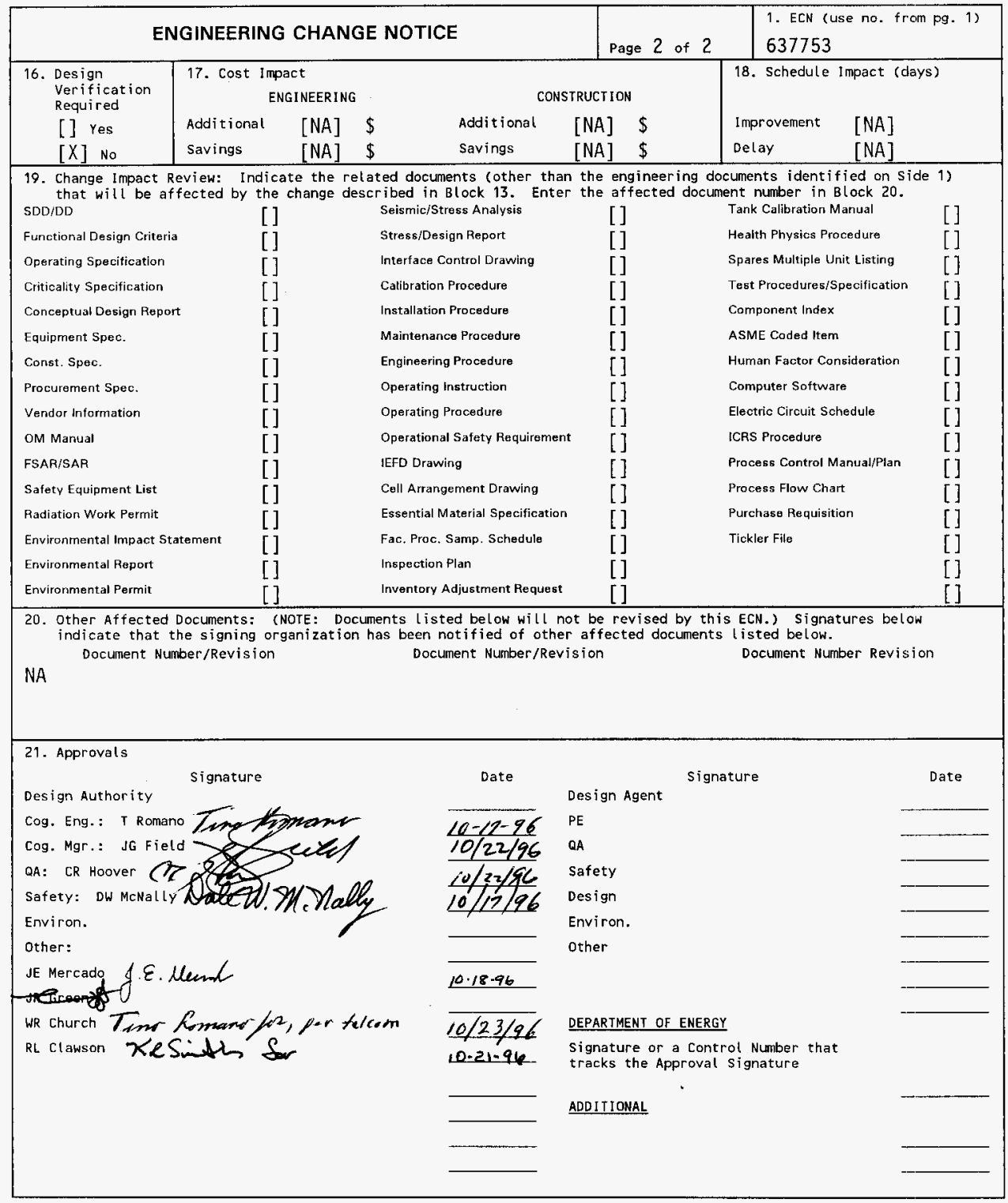




\section{FFTF Railroad Tank Car Safety Evaluation for Packaging}

\section{T. Romano}

Rust Federal Services of Hanford, Inc., Richland, WA 99352

U.S. Department of Energy Contract DE-AC06-87RL10930

$\begin{array}{lll}\text { EDT/ECN: } & \text { ECN } 637753 & \text { UC: } 513 \\ \text { Org Code: } & 84100 & \text { Charge Code: } \\ \text { B\&R Code: } & \text { EX7002000 } & \text { Total Pages: } 9\end{array}$

Key Words: Fast Flux Test Facility, Liquid Waste Tank Car, low specific activity, equivalent safety

Abstract: This Safety Evaluation for Packaging (SEP) provides evaluations necessary to approve transfer of the 8,000 gallon Liquid Waste Tank Car (LWTC) from the Fast Flux Test Facility (FFTF) to the 200 Areas. This SEP will demonstrate that the transfer of the LWTC will provide an equivalent degree of safety as would be provided by packages meeting U.S. Department of Transportation (DOT) requirements. This fulfills onsite transportation requirements implemented in the Hazardous Materia7 Packaging and Shipping, WHC-CM-2-14. TRADEMARK DISCLAIMER. Reference here in to any specific commercial product, process, or service by
trade name, trademark, manufacturer, or otherwise, does not necessarily constitute or imply its
endorsement, recommendation, or favoring by the United states Government or any agency thereof or $i$ ts contractors or subcontractors.

Printed in the United States of America. To obtain copies of this document, contact: WHC/BCS Document Control Services, P.O. Box 1970, Mailstop H6-08, Richland WA 99352, Phone (509) 372-2420; Fax (509) 376-4989.

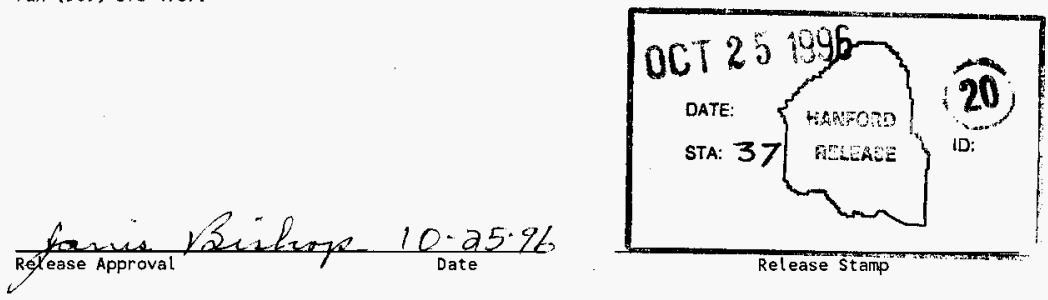

\section{Approved for Public Release}


RECORD OF REVISION

(1) Document Number

WHC-SD-TP-SEP-040

Page 1

(2) Title

FFTF Railroad Tank Car Safety Evaluation for Packaging

CHANGE CONTROL RECORD

\begin{tabular}{|l|l|} 
(3) Revision & (4) Description of Change - Replace, Add, and Delete Pages \\
\cline { 2 - 3 } 0 & (7) EDT 611657, dated 10/02/95. \\
\hline 1 RS & $\begin{array}{l}\text { The recent change of the low specific } \\
\text { activity (LSA) definition in Title 49 Code } \\
\text { of Federal Regulations (49 CFR) has } \\
\text { necessitated the need to update the } \\
\text { radioactive contents 1 imits for the FFTF } \\
\text { Railroad Tank Car. In addition, the } \\
\text { allowance for hot-spots has been } \\
\text { incorporated. Replace al1 pages. Per } \\
\text { ECN 637753. }\end{array}$ \\
\hline
\end{tabular}

\begin{tabular}{|l|l|}
\hline \multicolumn{2}{|c|}{ Authorized for Release } \\
\hline (5) Cog. Engr. & (6) Cog. Mgr. Date \\
\hline T Romano \\
Tro Kand \\
$10.23-16$
\end{tabular}

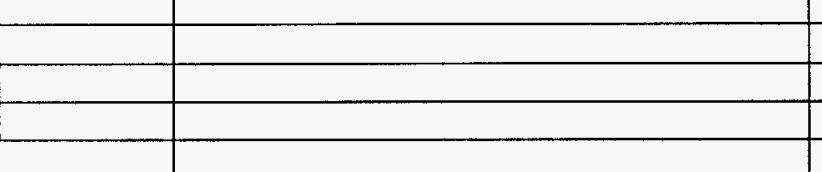




\section{WHC-SD-TP-SEP-040 Rev, 1}

\section{TABLE OF CONTENTS}

1.0 GENERAL INFORMATION . . . . . . . . . . . . . . . . . . . . . . . . . . . 1

2.0 PACKAGING DESCRIPTION . . . . . . . . . . . . . . . . . . . . 1

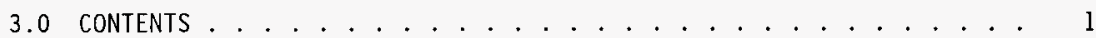

4.0 OPERATING REQUIREMENTS . . . . . . . . . . . . . . . . . . . . 2

4.1 GENERAL . . . . . . . . . . . . . . . . . . . 2

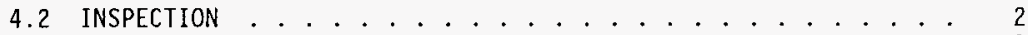

4.3 LOADING/UNLOADING . . . . . . . . . . . . . . . . . . 3

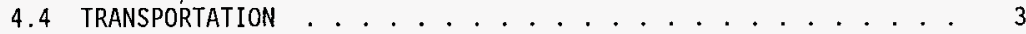

5.0 REFERENCES . . . . . . . . . . . . . . . . . . 5 


$$
\text { WHC-SD-TP-SEP-040 Rev, } 1
$$

\section{LIST OF TERMS}

$\begin{array}{ll}\text { ASTM } & \text { American Society for Testing and Materials } \\ \text { CFR } & \text { Code of Federal Regulations } \\ \text { DOT } & \text { U.S. Department of Transportation } \\ \text { ECN } & \text { Engineering Change Notice } \\ \text { FFTF } & \text { Fast Flux Test Facility } \\ \text { FRA } & \text { Federal Railroad Administrator } \\ \text { ICC } & \text { Interstate Commerce Commission } \\ \text { LSA } & \text { low specific activity } \\ \text { LWTC } & \text { Liquid Waste Tank Car } \\ \text { RSR } & \text { Radioactive Shipment Record } \\ \text { SEP } & \text { Safety Evaluation for Packaging }\end{array}$


WHC-SD-TP-SEP-040 Rev. 1

FFTF RAILROAD TANK CAR SAFETY EVALUATION FOR PACKAGING

\subsection{GENERAL INFORMATION}

This Safety Evaluation for Packaging (SEP) provides authorization for the use of the 8,000 gallon Liquid Waste Tank Car (LWTC) for interarea shipment of low-level radioactively contaminated 1 iquid waste from the Fast Flux Test Facility (FFTF) in the 400 Area to the 200 Areas for waste disposal. Preparation of a SEP is necessary to document the onsite transportation safety requirements implemented in Hazardous Material Packaging and Shipping, WHC-CM-2-14. This SEP also authorizes movement of the empty LWTC and deletes the internal inspection requirement for the LWTC Tisted in Title 49 Code of Federal Regulations Section 173.31(c)(3) (49 CFR 173.31(c)(3)).

The SEP will approve transfer of the LWTC within 5 years from date of issue unless otherwise designated by issue of an Engineering Change Notice (ECN).

\subsection{PACKAGING DESCRIPTION}

A reusable 8,000 gallon LWTC under the custody of FFTF, serial number $10 \mathrm{H}-03712$, is used for the interarea transport of radioactive contaminated 1 iquid waste. Waste shipments are made from the 400 Area and may be sent to approved load-out facilities in either 200 East or 200 West Areas. Transfer of the LWTC to these areas is also done for inspection and maintenance.

The LWTC was fabricated in 1953 in accordance with the Interstate Commerce Commission (ICC) specification 103-CW, which was later grandfathered by the U.S. Department of Transportation (DOT). Details of the LWTC fabrication are listed in drawing H-4-63895 (WHC 1980).

The tank car is constructed of American Society for Testing and Materiais (ASTM) A240 Type 430 steel and has an 8,000 gallon capacity. Hood and shelf couplers designated by the American Railroads catalog approved by the Federal Railroad Administrator (FRA), which are equipped with automatic couplers that will resist car telescoping and jackknifing in derailments and in emergency stops, were installed on the LWTC which bring the LWTC in compliance with 49 CFR 179.14. A 1 idded sealed cupola provides a containment barrier for fittings valves, and flanges during transport and storage.

\subsection{CONTENTS}

The radioactive materials to be transported in the 8,000 gallon LWTC are FFTF waste solutions consisting of low specific activity (LSA)-I solutions as defined in 49 CFR 173.403 . 


$$
\text { WHC-SD-TP-SEP-040 Rev. } 1
$$

\subsection{OPERATING REQUIREMENTS}

\subsection{GENERAL}

1. All applicable instructions and procedures for onsite shipments of radioactive materials specified in $W H C-C M-2-14$, shall be followed.

2. The 8,000 gallon LWTC or the design shall not be altered or revised without documented approval obtained by Packaging Engineering.

3. Unless otherwise noted in Section 4.2.2, it shall be verified that the 8,000 LWTC complies with the 103-CW specification (49 CFR 179.200-1).

4. Unless otherwise noted in Section 4.2.2, the inspections of the 8,000 galion LWTC shall be done according of 49 CFR 173.31, "Qualification, maintenance, and use of tank cars" prior to LWTC usage.

5. Transport shall be exclusive use.

\subsection{INSPECTION}

1. The loaded LWTC stored outdoors shall be visually inspected for leaks and abnormal conditions at least once a day.

2. Prior to departure (unloaded or full), the LWTC shall be inspected for potentially hazardous conditions as follows:

- Car body leaning or listing, sagging, objects dragging below or extending the side, any broken or missing safety appliances.

- Leaking of contents from the LWTC.

- Any other condition considered likely to cause an accident before the train arrives at its destination.

- The shipper must determine to extent practicable, that the tank, safety appurtenances, and fittings are in proper condition for the safe transportation.

- Tanks or trains which show any of the defects mentioned must not be offered for transportation until proper repairs have been made by the appropriate personnel.

3. Prior to loading of the LWTC, verify that the brakes and running gear preventive maintenance inspection is current.

4. Retest and inspection of the LWTC must be conducted prior to usage and include the following: 


$$
\text { WHC-SD-TP-SEP-040 Rev. } 1
$$

- Completely filling the tank car with water or other liquid of similar viscosity and pressure test to $60 \mathrm{psi}$

(49 CFR 173.31, Table 1).

- The pressure relief valve tested to discharge at $35 \pm 3$ psi and vapor tight seal at 28 psi (49 CFR 171.31, Table 1).

NOTE: Internal inspections as stated in 49 CFR 173.31(c)(3) shall not be required.

5. Records of inspection and preventive maintenance of the LWTC shall be retained for the life of the container to furnish evidence of activities affecting quality.

\subsection{LOADING/UNLOADING}

1. Tank car loading and unloading shall be scheduled to minimize outdoor storage of the loaded tank car.

2. The tank car shall be filled under strict liquid level control (weight factor instrument and load out tank material balance) to avoid water hammer damage to the rupture disc, and to avoid pressurizing the tank with loading pump pressure.

3. The shipper shall verify by analyses or testing that the radioactive limits are met prior to all shipments.

4. Transport of materials described in Section 3.0 shall be in accordance with 49 CFR 173.427 (a) and 173.427 (c)(2)(I).

\subsection{TRANSPORTATION}

1. The shipper shall provide an accurate description of the radiological conditions of the shipment to the receiving facility by:

- Telephone conversation prior to shipment, and on the Radioactive Shipment Record (RSR) delivered by the train crew.

2. Train speed shall not exceed $3 \mathrm{mph}$ while coupling.

3. The LWTC shipment shall not move at a speed in excess of $25 \mathrm{mph}$ while full, unloaded, or on any route. Speed shall not exceed $10 \mathrm{mph}$ on any paved road crossing or under the following conditions:

- Inside limited areas,

- During icy or snowy conditions, or

- When visibility is hampered due to fog, smoke, or haze. 


$$
\text { WHC-SD-TP-SEP-040 Rev. } 1
$$

Speed shall not exceed $5 \mathrm{mph}$ (exiting or entering) while on a rail spur of any facility.

4. Trains or other railroad equipment shall be safely separated by dispatcher control of train and equipment movement. Hanford railroad dispatcher control and train order practices shall apply.

5. To minimize the possibility of a train and vehicle collision, all tank car shipments that cross paved roads outside limited areas shall have a patrol blockade of the road on each side of the rail crossing to stop vehicle traffic. When the train approaches the crossing, the engineer shall signal traffic by blowing the train horn and shall slow the train to $10 \mathrm{mph}$.

6. The train shall consist of the locomotive, and at least one spacer car on each end of the LWTC.

7. At least one person in the cab of the locomotive must keep the cars under observation at all times while the train is moving.

8. The train shall consist of the locomotive with one to four spacer cars between it and a single tank car. One or more spacer cars shall follow the tank car. The total number of cars behind the locomotive shall not exceed the three to seven mentioned here. The number of spacer cars used shall be dependent on the dose rate received by personnel in the cab of the locomotive and received by other essential personnel during transfer.

9. The tank car shall be towed rather than pushed whenever possible.

10. The tank car shall not be left unattended enroute.

11. The tank car shall not travel past the interchange tracks of the 1100 Area.

12. Tank Farms Surveillance Operations, Operational Health Physics, Radiation Protection, and Packaging Engineering shall be notified of all accidents involving radioactive material shipment that result in vehicle damage, container damage, and/or personnel injury, or contamination.

13. Access to tank contents (full or unloaded tank car) must be sealed with a security seal, which is not readily breakable, and while intact, would be evidence that the package has not been opened by unauthorized persons.

NOTE: The unloaded LWTC shall be transported in the same manner as a loaded LWTC and all operating requirements stated in this SEP shall apply. Hot spots are allowed provided they do not exceed $10 \mathrm{mSv} / \mathrm{h}$ ( $1 \mathrm{rem} / \mathrm{h}$ ) at $3 \mathrm{~m}$ from the unshielded material. 


$$
\text { WHC-SD-TP-SEP-040 Rev. } 1
$$

\subsection{REFERENCES}

49 CFR 173, 1996, "Packaging and Transportation of Radioactive Materials," Code of Federal Regulations, as amended.

49 CFR 179, 1996, "Specifications for Tank Cars," Code of Federal Regulations, as amended.

WHC-CM-2-14, Hazardous Material Packaging and Shipping, Westinghouse Hanford Company, Richland, Washington.

WHC, 1980, 8000 Gallon Tank Car Cupola Modifications and Transition Attachments, drawing H-4-63895, Westinghouse Hanford Company, Richland, Washington. 


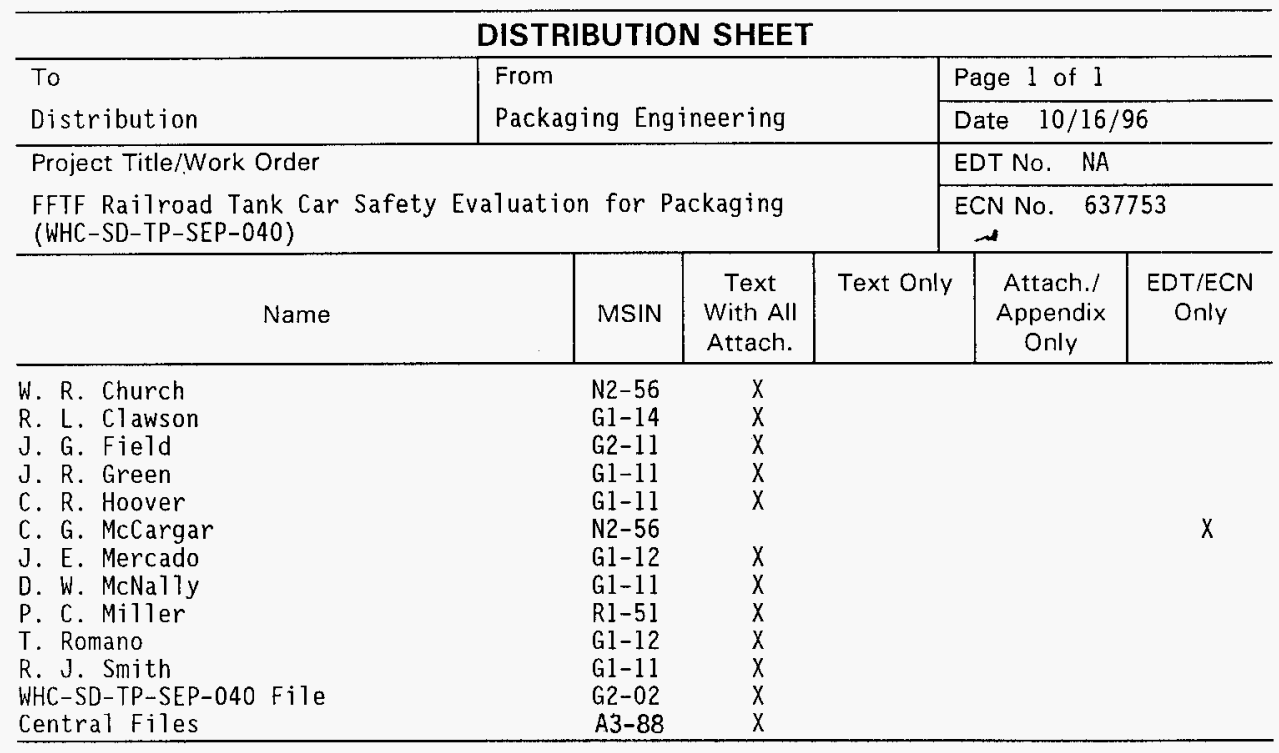

